\section{Factors Affecting Income Distribution in Sulawesi}

Andi Riyanto ${ }^{1}$, Syarwani Canon ${ }^{2}$, Ivan Rahmad Santoso ${ }^{3}$

${ }^{1}$ Economic Faculty, Universitas Negeri Gorontalo, Indonesia

${ }^{2}$ Economic Faculty, Universitas Negeri Gorontalo, Indonesia

${ }^{3}$ Economic Faculty, Universitas Negeri Gorontalo, Indonesia

Email: andi14riyanto@gmail.com

Abstract: This study aims to determine the factors that influence the distribution of income in Sulawesi. The data used is data sourced from the Central Statistics Agency, for the period 2011-2020 in 6 Sulawesi Island Provinces. The method used is multiple regression analysis with the help of the eviews 9 application. The results show that per capita expenditure has a positive and significant effect on income distribution, average years of schooling has a negative and significant effect on income distribution, life expectancy has a negative but not significant effect on income distribution.

Keywords: Income Distribution; Expenditure; Average Years of Schooling; Life Expectancy
Article History:

Received on 10 Jan 2022

Revised on 12 Jan 2022

Accepted on 15 Jan 2022

Doi: 10.37479

Indexing:

Google Scholar; Portal

Garuda; Crossref; SINTA 5

(Science And Technology Index)

The journal allows the authors to hold the copyright without restrictions and allow the authors to retain publishing rights without restrictions. international license.

\title{
INTRODUCTION
}

Basically, each country has the main goal of increasing the standard of living or the peace of its entire population through increasing the economic development of a country. Economic development is a must if a country wants to improve the standard of living and peace of its population. In other words, economic development is a conscious and directed effort of a community group to raise the standard of living of its population through the use of existing resources. This increase in peace can be measured, among others, by the increase in national income or the high rate of economic growth every year. According to Sukirno, 2006 (In Suzana and Kapantow, 2014).

Welfare is an important part of a country, the problem faced by developing countries is the welfare of their citizens. In fact, the establishment or establishment of a State is one of the goals in the context of realizing prosperity for its people. Various methods, methods, rules, tools, approaches, or policies have been chosen, adopted and carried out by a country in order to achieve these goals.

The problem of income distribution is something that often happens and is accepted by every society. One way to increase income distribution is to increase existing resources and equitable economic development. According to Suryono, 2000 (In Suzana and Kapantow, 2014). Stating that economic development is a process that causes the per capita income of a population or a society in a long period of time. Therefore, it is necessary to carry out sustainable economic development and be carried out properly and evenly, because the implementation of economic development will encourage economic growth and increase income distribution for the welfare of the community.

The distribution of income based on the owner of the production factors will be related to the income growth process, while the income growth in society based on the ownership of the production factors can be grouped 
into two types, namely (1) Income due to work results in the form of wages and salaries or the amount depends on the level of income. productivity; and (2) income from other sources such as rent, profit, interest, gifts, or inheritance, but the relevance of functional theory does not affect the importance of the role and influence of forces outside the market (non-economic factors) such as power in determining factors price. (Laloan et al, 2018).

GRDP is the amount of gross value added (gross value added) arising from all economic sectors in a region within a certain period of time. The components of gross value added include the components of income factors (wages and salaries, interest, land rent and profits), so by calculating the gross added value of each sector and then adding them up, it will produce the Gross Regional Domestic Product (GRDP).

Comparison is a picture of the results of development between one region and another, this picture can be seen by aligning the figures for the Gross Regional Domestic Product in each province. The comparison used is GRDP at the base price at constant prices.

Table 1. Growth Rate of Gross Regional Domestic Population at Constant Prices

\begin{tabular}{|c|c|c|c|c|c|}
\hline \multirow{2}{*}{ Province } & \multicolumn{5}{|c|}{ Years (\%) } \\
\cline { 2 - 6 } & $\mathbf{2 0 1 6}$ & $\mathbf{2 0 1 7}$ & $\mathbf{2 0 1 8}$ & $\mathbf{2 0 1 9}$ & $\mathbf{2 0 2 0}$ \\
\hline North Sulawesi & 6,16 & 6,31 & 6,00 & 5,65 & $-0,01$ \\
\hline Central Sulawesi & 9,94 & 7,10 & 20,60 & 8,83 & 4,86 \\
\hline South Sulawesi & 7,42 & 7,21 & 7,04 & 6,91 & $-0,70$ \\
\hline Southeast Sulawesi & 6,51 & 6,76 & 6,40 & 6,50 & $-0,65$ \\
\hline Gorontalo & 6,53 & 6,73 & 6,49 & 6,40 & $-0,02$ \\
\hline West Sulawesi & 6,01 & 6,39 & 6,26 & 5,67 & $-2,42$ \\
\hline
\end{tabular}

Based on Table 1, the GRDP at constant prices according to the 6 provinces on the island of Sulawesi, the order from the largest to the smallest is Central Sulawesi Province, South Sulawesi Province, Gorontalo Province, Southeast Sulawesi Province, North Sulawesi Province, and the last is the province of West Sulawesi.

There are three indicators that make up the composition as a comparison of HDI measurements, namely, the level of health, education level, and the level of the economy. These three indicators influence each other. So to increase the HDI, the government must pay attention to these three elements, besides that, it is also necessary to pay attention to the supporting factors.

Table 2. Human Development Index by Province In sulawesi 2016-2020

\begin{tabular}{|c|c|c|c|c|c|}
\hline \multirow{2}{*}{ Province } & \multicolumn{5}{|c|}{ Years (\%) } \\
\cline { 2 - 6 } & $\mathbf{2 0 1 6}$ & $\mathbf{2 0 1 7}$ & $\mathbf{2 0 1 8}$ & $\mathbf{2 0 1 9}$ & $\mathbf{2 0 2 0}$ \\
\hline North Sulawesi & 71,05 & 71,66 & 72,20 & 72,99 & 72,92 \\
\hline Central Sulawesi & 67,47 & 68,11 & 68,88 & 69,50 & 69,55 \\
\hline South Sulawesi & 69,76 & 70,34 & 70,90 & 71,66 & 71,93 \\
\hline Southeast Sulawesi & 69,31 & 69,86 & 70,61 & 71,20 & 71,45 \\
\hline Gorontalo & 66,29 & 67,01 & 67,71 & 68,49 & 68,68 \\
\hline West Sulawesi & 63,60 & 64,30 & 65,10 & 65,73 & 66,11 \\
\hline
\end{tabular}

Source: Badan Pusat Statistik

According to Susenas data, the Human Development Index in the last 5 years between Provinces in Sulawesi and Provinces which have the highest Human Development Index reaching 17\%, there are 4 provinces, namely North Sulawesi, Central Sulawesi, South Sulawesi, Southeast Sulawesi, Gorontalo and West Sulawesi Provinces. reached a value of $16 \%$

The Human Development Index is a concise measure of the average achievement of the main dimensions of human development, namely a long and healthy life, having knowledge, and having a decent standard of living. And to realize good human development, these three dimensions must receive equal attention because these three dimensions are equally important.

\section{Relationship Between Human Development Index (HDI) With Income Distribution}

According to Becker (Tirmidhi, 2012), stating that HDI has a negative effect on inequality, Becker examines more deeply about the role of formal education in supporting economic growth stating that the higher the formal education obtained, the higher labor productivity will be. This is in accordance with the theory of human capital, namely that education has an influence on economic growth and will reduce income disparities because education plays a role in increasing labor productivity. This theory assumes that population growth is determined by individual productivity. If everyone has a higher income because of higher education, the population's economic growth can be supported, with economic growth either directly or indirectly having a negative effect on income inequality. 
There are three dimensions of measuring the quality of human life, the first is the health dimension, the second is the education dimension, and the third is a decent standard of living. In a broader scope, a decent standard of living describes the level of welfare enjoyed by the population as a result of the improving economy. The ability of people's purchasing power to a number of basic needs as seen from the average amount of per capita expenditure as an income approach that represents development achievements for a decent life. The level of welfare is said to be increasing if there is an increase in real per capita consumption, i.e. the nominal increase in household expenditure is higher than the inflation rate in the same period.

\section{The Relationship Between Average Years of Schooling on Income Distribution}

The higher a person's education level, the knowledge and skills will also increase so that it will encourage an increase in one's productivity. The company will get more results by employing workers with higher productivity, so the company will be willing to provide higher wages/salaries to those concerned. In the end, someone who has high productivity will get better welfare, which can be shown through an increase in income and consumption, this can also increase income distribution because the productive number will increase and there will be more qualified graduates.

\section{The Relationship Between Life Expectancy and Income Distribution}

Life Expectancy Rate $(\mathrm{AHH})$ is a tool to evaluate the government's performance in improving the welfare of the population in general, and improving health status in particular. In comparing the level of welfare between community groups, it is very important to look at the life expectancy. In countries with better health, individuals live longer on average, thus economically having the opportunity to earn higher incomes. Furthermore, Lincolin (1999) explains that intervention to improve health from the government is also an important policy tool to reduce poverty. One of the factors underlying this policy is that improved health will increase the productivity of the poor, better health will increase work power, reduce days off work and increase energy output.

\section{METHODOLOGY}

The research data collection covered 6 provinces on the island of Sulawesi, namely North Sulawesi, Central Sulawesi, South Sulawesi, Southeast Sulawesi, Gorontalo, West Sulawesi. This research is a quantitative research. The data used in this research is secondary data. The data obtained are data from various related literature in the form of documents or archives. The data obtained are then compiled and processed according to the interests and objectives of the study, for research purposes where the data needed is comparative data between the islands of Sulawesi, namely by covering data, Per capita Expenditures, Average Years of Schooling, Life Expectancy, with the data period in take from 2016 to 2020. The analytical model used is Commonn Effect Model (CEM), Fixed Effect Model (FEM), Random Effect Model (REM), T test, and F test.

\section{DISCUSSION}

\section{Effect of Per capita Expenditure on Income Distribution}

From the estimation results that have been done previously, it shows that per capita expenditure has a positive and significant effect on income distribution. This means that an increase in per capita expenditure will increase the distribution of income on the island of Sulawesi. These results indicate that the higher the per capita expenditure of the population on the island of Sulawesi directly results in an improved income distribution of the population. Because it is assumed that the high per capita expenditure of the population is caused by the high per capita income of the population. Vice versa, the low per capita expenditure of the population is also caused by the low per capita income of the population.

\section{Effect of Average Length of School on Income Distribution}

From the estimation results that have been done previously, it shows that the average length of schooling has a negative and significant effect on the distribution of income on the island of Sulawesi. This means that the average length of schooling can reduce or result in a decrease in the distribution of income on the island of Sulawesi. Because the level of education, in this case, the high average length of schooling can increase job opportunities and also the productivity of the community. The longer you go to school or the higher the level of education you take will actually improve a person's quality and ability so that it will be easier to compete in the world of work and in the business world, so that it will increase productivity and will affect a person's income.

\section{Effect of Life Expectancy on Income Distribution}

From the estimation results that have been done previously, it shows that life expectancy has a negative but not significant effect on the distribution of income on the island of Sulawesi. This means that a high life expectancy does not necessarily reduce the distribution of income on the island of Sulawesi. The results of this study indicate that the age of the population has no effect on the distribution of income. Residents who are in productive or 
unproductive age should actually continue to encourage income distribution or in other words, the population must remain productive even though they are old. However, most of the elderly population in each region depend largely on the productive age population. The unproductive age of the elderly population will have an impact on the decline in income and consumption of the elderly population. This research is in line with research conducted by Handayani et.al (2016) which states that life expectancy is not significant to GRDP per capita. Long life expectancy, not accompanied by skills, will only add to the burden of regional development.

\section{CONCLUSION}

1. Per capita expenditure has a positive and significant effect on income distribution. This means that every increase in per capita expenditure will increase the distribution of income on the island of Sulawesi.

2. The average length of schooling has a negative and significant effect on the distribution of income. This means that every increase in the average length of schooling can reduce the income distribution of the people on the island of Sulawesi.

3. Life expectancy has a negative but not significant effect on income distribution. This means that the high life expectancy does not necessarily reduce the income distribution of the people on the island of Sulawesi.

\section{REFERENCES}

Almizan. (2016). Distribusi Pendapatan Kesejahteraan Menurut Konsep. Volume 1, No.1, Januari-Juni 2016.

Amri, H. (2017). Analisis Pertumbuhan Ekonomi Dan Ketimpangan. Vol.1 | No.1 | 2017.

Arif, A. A. (2018). Analisis Faktor-Faktor Yang Mempengaruhi Ketimpangan Distribusi Pendapatan Antar Provinsi Di Pulau Sumatera Tahun 2014-2016.

Ariyani, T. H. (2019). Distribusi Pendapatan Di Indonesia.

Bella Fitria Laloan, G. H. (2018). Distribusi Pendapatan Antar Daerah Di Provinsi Sulawesi Utara. Volume 14 Nomor 2, Mei 2018 , 121-130.

Dr. Ir. Benu Olfie L. Suzana, M. D. (2015). Faktor-Faktor Yang Mempengaruhi Distribusi Pendapatan Di Sulawesi Utara.

Dwiputra, R. M. (2011-2021). Analisis Faktor-Faktor Yang Mempengaruhi Ketimpangan Pendapatan Di Indonesia.

Hartini, N. T. (2017). Pengaruh Pdrb Per Kapita, Investasi Dan Indeks Pembangunan Manusia Terhadap Ketimpangan Pendapatan Antar Daerah Di Provinsi Daerah Istimewa Yogyakarta Tahun 2011-2015.

Indrasuara Luther Sirangi Si'lang, Z. H. (2019). Analisis Faktor-Faktor Yang Berpengaruh Terhadap Indeks Pembangunan Manusia. Vol. 11 (2) 2019, 159-169.

Kartika, M. (2014). Faktor-Faktor Yang Mempengaruhi Ketimpangan Distribusi Pendapatan Di Sulawesi Selatan Periode 2003-2021.

Ma'sum, M. A. (2020). Analisis Faktor Yang Mempengaruhi Ketimpangan Distribusi Pendapatan Di Kabupaten Banyumas Tahun 2011-2018.

Musfidar, M. (2012). Faktor-Faktor Yang Mempengaruhi Ketimpangan Distribusi Pendapatan Di Sulawesi Selatan Tahun 2001-2010.

Sarina. (2019). Analisis Faktor-Faktor Yang Mempengaruhi Ketimpangan Distribusi Pendapatan Kabupaten/Kota Di Provinsi Sulawesi Selatan Tahun 2008-2017.

Statistik, Badan Pusat (2016-2020). Indeks Pembangunan Manusia.

Statistik, Badan Pusat (2016-2020). Produk Domestik Regional Bruto. 